\title{
Clinical Utility of Red Blood Cell Distribution Width Parameter in Patients with Hemodynamically Stable Acute Pulmonary Embolism
}

\author{
Ahmet Cemal Pazarlıํㄹ Lütfui Bekar ${ }^{2}$ \\ ${ }^{1}$ Department of Chest Diseases, Elbistan State Hospital, Kahramanmaraş \\ ${ }^{2}$ Department of Cardiology, Tokat State Hospital, Tokat
}

\begin{abstract}
Objective: Patients with acute pulmonary embolism (PE) presenting with persistent hypotension or shock are considered to be high-risk, while hemodynamically stable patients with acute PE are classified as low- or moderate-risk, depending on their right ventricular dysfunction and/or levels of biomarkers indicating myocardial injury. In this study, we assessed the clinical benefits of knowing the red cell distribution width (RDW) parameter in patients with hemodynamically stable acute PE.
\end{abstract}

\begin{abstract}
Methods: All patients diagnosed with acute PE in our hospital between 2008 and 2010 were retrospectively included in the study. Patients with hypotension, a history of malignancy, heart failure, and/or anemia were excluded. Patients with normotensive acute PE were divided into either a low- or moderate-risk group. This classification was made according to echocardiographic right ventricular dysfunction, positive troponin $\mathrm{T}$, and the level of NT-proBNP. Red cell distribution width values of low and moderate acute PE risk groups were compared.
\end{abstract}

Results: Thirty-two patients were assessed as moderate-risk and 34 patients were low-risk PE. Red cell distribution width values of the moderate-risk group were significantly higher than those of the low-risk group ( $14.77 \pm 0.54$ vs. $14.09 \pm 0.43 ; p=0.036$, respectively).

Conclusion: Analysis of RDW values can help to determine the low and moderate risk levels of hemodynamically stable patients with acute PE.

Keywords: Acute pulmonary embolism, red blood cell distribution width, risk classification

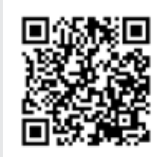

Received date: 19.04 .2013 Accepted date: 24.08 .2013

Address for correspondence Ahmet Cemal Pazarl, Department of Chest Diseases, Elbistan State Hospital, Kahramanmaraş, Turkey E-mail: cpazarli@hotmail.com

(C) Copyright 2014 Turkish Respiratory Society (TRS) DOI: 10.5152/ejp.2014.64872

-Available online at www.eurasianjpulmonol.com

\section{INTRODUCTION}

The determination of risk classification and course of treatment must be made at the same time in patients presenting with acute pulmonary embolism (PE). Further laboratory tests are not necessary in the treatment of hemodynamically unstable (shock or hypotension) PE patients, since this group is accepted as high-risk. However, further tests are necessary when planning the treatment of normotensive PE patients. Patients with low risk are often discharged in the early period, while PE patients with moderate risk are often hospitalized longer (1). Indicators of ventricular dysfunction and/or myocardial damage are sought for the risk classification of normotensive acute PE patients (1-5). Right ventricular dysfunction is usually evaluated by an echocardiographic examination and levels of natriuretic peptide, while myocardial damage is evaluated by measuring troponin levels (1). However, there are often difficulties in making the risk classification. Right ventricular functions may fail to be evaluated because of the poor echogenicity in persons with obesity and chronic lung disease, and biomarker levels may not be high at the time of admission $(6,7)$. Red cell distribution width (RDW) is a quantitative indicator of the size variability of red blood cells. This parameter can be easily obtained from a full blood count and is accepted as an indicator of ineffective red cell production (8). Some studies have suggested that RDW may be associated with cardiovascular and pulmonary diseases (9-14). In this study, we aimed to investigate RDW values in patients presenting with hemodynamically stable acute PE.

\section{METHODS}

Patients diagnosed with acute PE in our hospital between 2008 and 2010 were retrospectively studied. Patients with hypotension, malignancy, history of heart failure, and/or anemia were excluded 


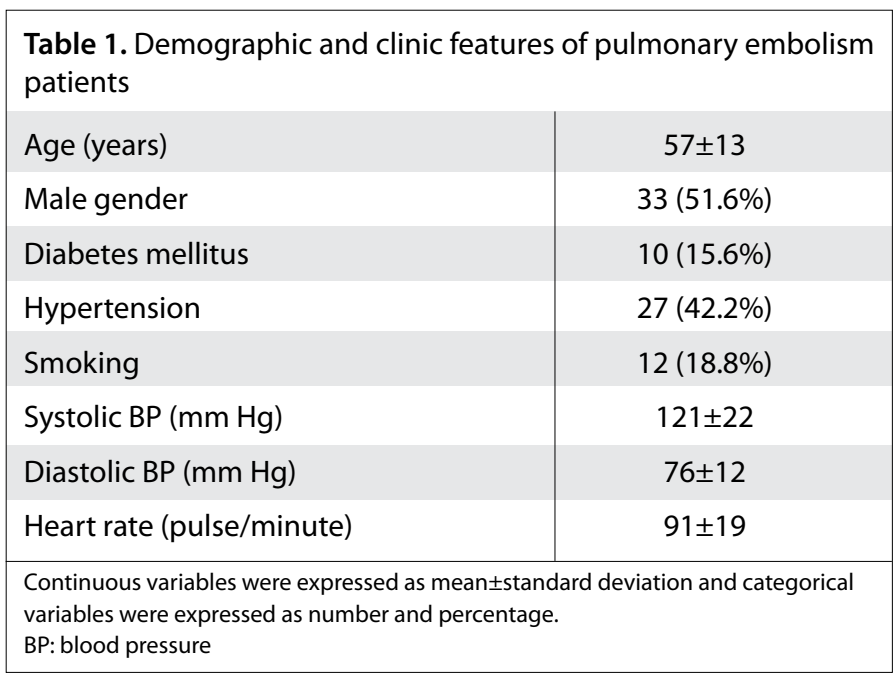

Table 2. Characteristics of the patients with acute pulmonary embolism

\begin{tabular}{|l|c|c|}
\hline & $\mathbf{n}$ & $\%$ \\
\hline Presentation complaints & 34 & 53.1 \\
\hline Shest pain & 41 & 64.1 \\
Coughing & 14 & 21.9 \\
Hemoptysis & 10 & 15.8 \\
\hline Syncope & 1 & 1.56 \\
\hline Predisposing factors & 11 & \\
\hline History of deep vein thrombosis & 3 & 4.7 \\
Collagen tissue disease & 5 & 7.8 \\
Use of oral contraceptives & 27 & 42.2 \\
\hline History of immobilization & 18 & 28.1 \\
\hline History of previous surgery & 9 & 14.1 \\
\hline Troponin T positivity & & \\
\hline Right ventricular dysfunction & 17 & 26.6 \\
\hline NT-proBNP elevation & 26 & 40.6 \\
\hline Echocardiographic & & \\
\hline NT-proBNP: N-terminal pro B-type natriuretic peptide & & \\
\hline
\end{tabular}

from the study. The diagnosis of acute PE was confirmed with a multislice spiral computed tomography in all of the patients. Full blood count and measurements of troponin T and NT-pro BNP were carried out during admission, and records of transthoracic echocardiography, ordered within 24 hours, were used in this study. Patients having at least one of the criteria, which included echocardiographic right ventricular dysfunction and elevated NT-pro BNP or troponin T, were assigned to the moderate-risk PE group (1). Patients not having any of these criteria were included in the low-risk PE group (1). RDW measurements were obtained from an automatic full blood count device. The normal reference range of RDW was $11.7-14.3 \%$ in our laboratory. Anemia was defined as a hemoglobin value $<13 \mathrm{~g} / \mathrm{dL}$ in males and $<12 \mathrm{~g} / \mathrm{dL}$ in females (15). Levels of troponin T and NT-proBNP were measured from the same serum specimens (Roche Diagnostics GmBH-Germany). Troponin T $>0.01 \mathrm{ng} / \mathrm{mL}$ and NT- pro BNP $>1000$ $\mathrm{pg} / \mathrm{mL}$ were considered to be significant (16). Transthoracic echocardiography that was ordered within the first 24 hours was examined with a Philips Envisor C model echocardiography device and $3.2 \mathrm{mHz}$ adult probe. On transthoracic evaluation, right ventricular dysfunction was accepted as tricuspid regurgitation jet velocity $>2.6 \mathrm{~m} / \mathrm{sec}$, hypokinesis, or dilation in the right ventricular wall (right ventricular end-diastolic diameter/left ventricular end-diastolic diameter $>1$ in apical four-chamber) $(4,17)$.

\section{Statistical Analysis}

Continuous data are expressed as mean \pm standard deviation (SD), while categorical data are expressed as percentages. Differences in continuous data were analyzed with the student's t-test, and categorical data were compared with the chi-square test. A two-tailed $p$ value $<0.05$ was considered to be statistically significant. All statistical analyses were performed using the Statistical Package for the Social Sciences (SPSS) statistical software package (Version 12: SPSS Inc., Chicago, IL, USA).

\section{RESULTS}

Ninety-seven patients were diagnosed with acute PE between 2008 and 2010 in our hospital. Thirty-three of these patients were excluded from the study due to hypotension (12), malignancy (12), heart failure (4), and anemia (5). The remaining 64 acute PE patients were included in the study. The most common presentation complaints in the acute PE group were shortness of breath (64\%) and chest pain (53\%), while 27 patients (42\%) had immobilization, 18 (28\%) had undergone surgery, 11 (17\%) had deep-vein thrombosis, 5 (8\%) used oral contraceptive drugs, and 3 patients (5\%) had a history of collagen tissue disease (Table 1). There was elevated troponin T in 9 (14\%) patients and elevated pro-BNP in 17 (\%27) patients upon admission, while right ventricular overload was found in 26 (41\%) patients on the echography performed within the first 24 hours. Based on the levels of troponin T and NT-proBNP and the echocardiographic findings, 32 patients were considered as having moderate risk and 34 were considered at low risk for PE (Table 2). RDW values were significantly higher in the moderate-risk group than in the low-risk group ( $14.77 \pm 0.54$ vs. $14.09 \pm 0.43, p=0.036$, respectively) (Table 3 ). Five patients were lost during the in-hospital follow-up (one of them was released with retroperitoneal hemorrhage after thrombolytic therapy). RDW values were significantly higher in PE patients who died in the hospital than in the survivors $(15.56 \pm 0.82$ vs. $14.32 \pm 0.43, p<0.049$, respectively).

\section{DISCUSSION}

Pulmonary embolism is a relatively infrequent cardiovascular emergency that accounts for $0.4 \%$ of hospital presentations (18). The mortality rates of the disease differ according to the clinical condition. Therefore, it is important to make an appropriate risk classification in patients diagnosed with PE (19). Risk classification begins with hemodynamic examination and continues with laboratory testing. $\mathrm{Hy}$ potensive $P E$ is a life-threatening emergency situation requiring specific treatment. Reperfusion therapy should be administered quickly in these patients, who often have high mortality $(2,3)$. Treatment strategy in normotensive PE patients has been a controversial issue. An appropriate treatment should be initiated rather than waiting to see the patient's outcome, which may be hemodynamic impairment (20). The mortality rate is $2 \%$ in low-risk PE, while it can be as high as 
Table 3. RDW values in the patients with low vs. moderate risk for pulmonary embolism

\begin{tabular}{|l|c|c|c|} 
& $\begin{array}{c}\text { Low risk PE } \\
(\mathbf{n}=34)\end{array}$ & $\begin{array}{c}\text { Moderate risk PE } \\
(\mathbf{n}=30)\end{array}$ & $\begin{array}{c}\mathbf{P} \\
\text { values }\end{array}$ \\
\hline $\mathrm{RDW}(\%)$ & $14.09 \pm 0.43$ & $14.77 \pm 0.54$ & 0.036 \\
$\mathrm{Hg}(\mathrm{g} / \mathrm{dL})$ & $13.30 \pm 1.10$ & $13.36 \pm 1.17$ & 0.164 \\
\hline $\mathrm{PLT}(\mathrm{x} 109 / \mathrm{L})$ & $297 \pm 126$ & $295 \pm 88$ & 0.424 \\
\hline
\end{tabular}

Variables were expressed as mean \pm standard deviation.

Hg: hemoglobin; PLT: platelet; RDW: red cell distribution width

$15 \%$ in patients with moderate-risk PE (19). Thrombolytic therapy is administered in normotensive PE patients with moderate risk (those not having increased risk for hemorrhage), while PE patients with low risk can be discharged early, provided they receive proper ambulatory care and anticoagulation therapy $(1,21)$. It may be difficult to perform risk classification in normotensive PE patients. Right ventricular functions may fail to be evaluated because of poor echogenicity in persons with obesity and/or chronic lung disease, and biomarker levels may not be high in the early periods $(6,7)$.

Red cell distribution width is a parameter that can easily be obtained from a simple full blood count in a short time. Recent studies have reported that RDW may be associated with cardiovascular and pulmonary diseases (9-14). RDW has been demonstrated to be a prognostic indicator in symptomatic heart failure patients (9). In later studies, elevated RDW has been reported to be an independent predictor of mortality and morbidity in patients with heart failure (22-25). It has been shown to be a stronger prognostic indicator than ejection fraction, functional capacity, renal Function, and pro-BNP (9). In a study investigating RDW elevation in coronary artery patients, it was shown that high RDW may be associated with cardiac death, non-fatal myocardial infarction, stroke, and new-onset heart failure $(11,13)$. In another study with patients having pulmonary hypertension (due to any reason), high RDW correlated with increased pressure of the right atrium (12). In a study investigating the significance of RDW in acute PE patients, hemodynamic parameters were demonstrated to be worse in patients with elevated RDW. High RDW was found to have high sensitivity but low specificity for early mortality in PE patients (14). In this study, we found that RDW was higher in PE patients than in the controls. When patients with low and moderate risk were compared following the risk classification, moderate-risk patients had a higher RDW value. In addition, RDW values were observed as higher in patients who died in the hospital compared to those that did not. The cause of elevated RDW in cardiovascular and pulmonary diseases has not been clearly elucidated. It may be due to other concomitant diseases, malnutrition, inflammatory cytokines, and increased neurohormonal activation $(9,10,12,26,27)$.

The main limitations of this study were that it was retrospective and that there was a small number of cases. Further prospective and extensive studies with a larger number of cases are needed.

\section{CONCLUSION}

Red cell distribution width is a parameter that can easily be obtained from a simple full blood count. High RDW at admission may be associated with an increased risk of mortality in acute PE patients. Such patients should be closely monitored for hemodynamic deteriora- tion. Furthermore, RDW values may provide insight into early risk classification in patients with right ventricular functions that could not be evaluated due to echogenicity or in patients with negative biomarkers during admission.

Ethics Committee Approval: Due to the retrospective design of the study the ethics committee approval was waived.

Informed Consent: Due to the retrospective design of the study the informed consent was not taken.

Peer-review: Externally peer-reviewed.

Author contributions: Concept - A.C.P., L.B.; Design - A.C.P., L.B.; Supervision - A.C.P., L.B.; Resource - L.B.; Materials - A.C.P., L.B.; Data Collection\&/or Processing - A.C.P., L.B.; Analysis\&/or Interpretation - L.B.; Literature Search - L.B.; Writing - A.C.P., L.B.; Critical Reviews - A.C.P.

Conflict of Interest: No conflict of interest was declared by the authors.

Financial Disclosure: The authors declared that this study has received no financial support.

\section{REFERENCES}

1. Torbicki A, Perrier A, Konstantinides S, Agnelli G, Galiè N, Pruszczyk P, et al. Guidelines on the diagnosis and management of acute pulmonary embolism: the task force for the diagnosis and management of acute pulmonary embolism of the european society of cardiology (ESC). Eur Heart J 2008; 29: 2276-315. [CrossRef]

2. Konstantinides S. Pulmonary embolism: impact of right ventricular dysfunction. Curr Opin Cardiol 2005; 20: 496-501. [CrossRef]

3. Kucher N, Rossi E, De Rosa M, Goldhaber SZ. Massive pulmonary embolism. Circulation 2006; 113: 577-82. [CrossRef]

4. Kreit JW. The impact of right ventricular dysfunction on the prognosis and therapy of normotensive patients with pulmonary embolism. Chest 2004; 125: 1539-45. [CrossRef]

5. Becattini C, Vedovati MC, Agnelli G. Prognostic value of troponins in acute pulmonary embolism: a meta-analysis. Circulation 2007; 116: 427-33. [CrossRef]

6. Kucher N, Goldhaber SZ. Cardiac biomarkers for risk stratification of patients with acute pulmonary embolism. Circulation 2003; 108: 2191-4. [CrossRef]

7. Puls M, Dellas C, Lankeit M, Olschewski M, Binder L, Geibel A, et al. Hearttype fatty acid-binding protein permits early risk stratification of pulmonary embolism. Eur Heart J 2007; 28: 224-9. [CrossRef]

8. Karnad A, Poskitt TR. The automated complete blood cell count. Use of the red blood cell volume distribution width and mean platelet volume in evaluating anemia and thrombocytopenia. Arch Intern Med 1985; 145: 1270-2. [CrossRef]

9. Felker GM, Allen LA, Pocock SJ, Shaw LK, McMurray JJ, Pfeffer MA, et al. Red cell distribution width as a novel prognostic marker in heart failure: data from the CHARM Program and the Duke Databank. J Am Coll Cardiol 2007; 50: 40-7. [CrossRef]

10. Tonelli M, Sacks F, Arnold M, Moye L, Davis B, Pfeffer M. Relation between red blood cell distribution width and cardiovascular event rate in people with coronary disease. Circulation 2008; 117: 163-8. [CrossRef]

11. Fukuta H, Ohte N, Mukai S, Saeki T, Asada K, Wakami K, et al. Elevated plasma levels of $\mathrm{B}$-type natriuretic peptide but not $\mathrm{C}$-reactive protein are associated with higher red cell distribution width in patients with coronary artery disease. Int Heart J 2009; 50: 301-12. [CrossRef]

12. Hampole CV, Mehrotra AK, Thenappan T, Gomberg-Maitland M, Shah SJ. Usefulness of red cell distribution width as a prognostic marker in pulmonary hypertension. Am J Cardiol 2009; 104: 868-72. [CrossRef]

13. Dabbah S, Hammerman H, Markiewicz W, Aronson D. Relation between red cell distribution width and clinical outcomes after acute myocardial infarction. Am J Cardiol 2010; 105: 312-7. [CrossRef]

14. Zorlu A, Bektasoglu G, Guven FM, Dogan OT, Gucuk E, Ege MR, et al. Usefulness of admission red cell distribution width as a predictor of early 
mortality in patients with acute pulmonary embolism. Am J Cardiol 2012; 109: 128-34. [CrossRef]

15. World Health Organization. Nutritional Anemia: Report of a WHO Scientific Group World Health Organization. Geneva: World Health Organization, 1968.

16. Binder L, Pieske B, Olschewski M, Geibel A, Klostermann B, Reiner C, et al. $\mathrm{N}$-terminal pro-brain natriuretic peptide or troponin testing followed by echocardiography for risk stratification of acute pulmonary embolism. Circulation 2005; 112: 1573-9. [CrossRef]

17. Kucher N, Goldhaber SZ. Risk stratification of acute pulmonary embolism. Semin Thromb Hemost 2006; 32: 838-47. [CrossRef]

18. Stein PD, Beemath A, Olson RE. Trends in the incidence of pulmonary embolism and deep venous thrombosis in hospitalized patients. Am J Cardiol 2005; 95: 1525-6. [CrossRef]

19. Wood KE. Major pulmonary embolism: review of a pathophysiologic approach to the golden hour of hemodynamically significant pulmonary embolism. Chest 2002; 121: 877-905. [CrossRef]

20. Goldhaber SZ. Acute pulmonary embolism: risk stratification. Pathophysiol Haemost Thromb 2006; 35: 153-6. [CrossRef]

21. Kearon C, Kahn SR, Agnelli G, Goldhaber S, Raskob GE, Comerota AJ. Antithrombotic therapy for venous thromboembolic disease: American college of chest physicians evidence-based clinical practice guidelines (8th Edition). Chest 2008; 133: 454S-545S.

22. Pascual-Figal DA, Bonaque JC, Redondo B, Caro C, Manzano-Fernandez SM, Sanchez-Mas J, et al. Red blood cell distribution width predicts long-term outcome regardless of anaemia status in acute heart failure patients. Eur J Heart Fail 2009; 11: 840-6. [CrossRef]

23. Jackson CE, Dalzell JR, Bezlyak V, Tsorlalis IK, Myles RC, Spooner R, et al. Red cell distribution width has incremental prognostic value to B-type natriuretic peptide in acute heart failure. Eur J Heart Fail 2009; 11:1152-4. [CrossRef]

24. Al-Najjar Y, Goode KM, Zhang J, Cleland JG, Clark AL. Red cell distribution width: an inexpensive and powerful prognostic marker in heart failure. Eur J Heart Fail 2009; 11: 1155-62. [CrossRef]

25. Van Kimmenade RR, Mohammed AA, Uthamalingam S, Van der Meer P, Felker GM, Januzzi JL. Red blood cell distribution width and 1-year mortality in acute heart failure. Eur J Heart Fail 2010; 12: 129-36. [CrossRef]

26. Kato H, Ishida J, Imagawa S, Saito T, Suzuki N, Matsuoka T, et al. Enhanced erythropoiesis mediated by activation of the renin-angiotensin system via angiotensin II type 1a receptor. FASEB J 2005; 19: 2023-5.

27. Gossman J, Burkhardt R, Harder S, Lenz T, Sedlmeyer A, Klinkhardt U, et al. Angiotensin II infusion increases plasma erythropoietin levels via an angiotensin II type 1 receptor-dependent pathway. Kidney Int 2001; 60: 83-6. [CrossRef] 